Pettit, N.E., Warfe, D.M., Kennard, M.J., Pusey, B.J., Davies, P.M. \& Douglas, M.M. (2013).

Dynamics of in-stream wood and its importance as fish habitat in a large tropical floodplain river. River Research and Applications. 29: DOI: 10.1002/rra.2580.

Published version on Journal website available at:

http://onlinelibrary.wiley.com/doi/10.1002/rra.2580/abstract 


\title{
Dynamics of in-stream wood and its importance as fish habitat in a large tropical floodplain river.
}

\author{
N.E. Pettit ${ }^{1,4}$, D. M. Warfe ${ }^{2,4}$, M.J. Kennard ${ }^{3,4}$, B. J. Pusey ${ }^{3,4}$, P.M. Davies ${ }^{1,4}$ and M.M. \\ Douglas $^{2,4}$ \\ ${ }^{1}$ Centre for Excellence in Natural Resource Management, The University of Western \\ Australia, Australia; ${ }^{2}$ Research Institute for the Environment and Livelihoods, Charles \\ Darwin University, Australia; ${ }^{3}$ Australian Rivers Institute, Griffith University, Brisbane, \\ Australia; ${ }^{4}$ Tropical Rivers and Coastal Knowledge, National Environmental Research \\ Program Northern Australia Hub.
}

\begin{abstract}
The recruitment of wood from the riparian zone to rivers and streams provides a complex habitat for aquatic organisms and can influence both aquatic biodiversity and ecosystem function. The Daly River in the wet-dry tropics of northern Australia is a highly seasonal, perennially-flowing sand-bed river where surveys of river wood aggregations at the reach scale $(\sim 2 \mathrm{~km})$ in 2008 and 2009 recorded densities of $37-78 \mathrm{~km}^{-1}$, and identified distinct types of river wood aggregations: key pieces, standing trees, fallen trees, wrack, and single pieces. After larger than average flows in the 2008/2009 wet season, between 46 and $51 \%$ of surveyed river wood had moved. Distribution of wood age classes indicated continual recruitment and slow turnover of wood within the river. Surveys of fish and habitat characteristics at the mesohabitat scale ( 100 m) showed fish species richness, diversity and fish abundance were not correlated to the proportion of wood present. Fish assemblage structure was associated with wood cover as well as other environmental variables such as stream width and depth. The importance of instream wood also varied for different species and age classes of fish. This study documents the dynamic nature of river wood aggregations and their complex and variable distribution, and suggests their importance as fish habitat in this tropical river.
\end{abstract}

Key words: large woody debris, fish assemblage, community structure, wood recruitment, Daly River, Katherine River, fish abundance, wood transport. 
River wood and fish habitat

Introduction

Riparian trees and branches are recruited into rivers to form in-stream aggregations of wood that can have long-term ecological effects on aquatic and riparian systems (Keller and Swanson, 1979; Bilby and Likens, 1980; Smock et al., 1989). Prevailing views of the ecological role of in-stream wood are driven primarily by an understanding of wood in mesic temperate systems (Lienkaemper and Swanson, 1987; Davies and Storey, 1998; Gregory et al., 2003; Latterell et al., 2003; Latterell and Naiman, 2007; Lester and Boulton 2008), with some research contributions from the semi-arid sub-tropics (Pettit et al., 2006) and the tropics (Arrington et al., 2005; Arrington and Winemiller, 2006). These studies demonstrate the importance of in-stream wood in providing habitat patches, a substrate for food resources, physical refuge, and spawning sites for fish and other aquatic biota. The spatial distribution and abundance of in-stream wood and its possible ecological importance has been little studied in tropical rivers, particularly in Australia.

In many Australian rivers, both tropical and temperate, riparian forests are dominated by hardwoods trees that are not buoyant so do not travel far downstream, and often wedge into the riverbed near the bank (Webb and Erskine, 2003). Over time, fluvial processes can add other pieces of wood to form a physical structure which accumulates sediments and creates a substrate and habitat for aquatic organisms (Crook and Robertson, 1999). By providing a stable substrate for the growth of periphyton and macroinvertebrates, river wood can increase primary and secondary productivity (Davies and Storey, 1998; Lester et al., 2007; Schneider and Winemiller, 2008; Entrekin et al., 2009), and provide food resources for grazing and insectivorous fish (Pusey and Arthington, 2003; Willis et al., 2005; Arrington and Winemiller, 2006). Another key role of in-stream wood is the provision of refuge habitat for aquatic biota, from predation and also high flows and associated turbulence and shear stress (Crook and Robertson, 1999; Pusey and Arthington, 2003; Willis et al., 2005; Arrington and Winemiller, 2006). Such habitat is particularly important in providing cover in rivers with extensive sand beds or where other forms of cover for aquatic fauna are scarce (Crook et al., 2001; Bond and Lake, 2003; Willis et al., 2005; Schneider and Winemiller, 2008). Deposited in-stream wood also interacts with river flows to produce other channel features which are important habitats for aquatic biota, such as scour pools and sand banks, and thus has a role in maintaining the heterogeneity of habitats within the river (Abbe and Montgomery, 2003; Brooks et al., 2003; Webb and Erskine, 2003; Naiman et al., 2008). 
River wood and fish habitat

The recruitment and downstream movement of in-stream wood is regulated by factors operating at multiple scales and is dependent on the structure and composition of the riparian vegetation, the individual architecture of in-stream wood (Gippel et al., 1996; Fremier et al., 2009), the nature of the stream channel (Lassettre et al., 2008), and hydrology. Recruitment of wood to the river from riparian forests is likely to occur sporadically, with the greatest input generally occurring during floods or periods of high flow via bank erosion and/or bank collapse (Lassettre et al., 2008; Pettit et al., 2006; Latterell and Naiman, 2007), but also during the falling limb of flood flows (Cadol et al., 2009).

Rivers in northern Australia display high interannual variability and strong seasonality, with most flow occurring over only a few months (Kennard et al., 2010; Warfe et al., 2011), and this variability is often more pronounced than that of other tropical regions (Lewis, 2008). While there is an emerging understanding of how these large wet season flows affect biotic assemblages on tropical Australian floodplains (Finlayson, 2005; Pettit et al., 2011), there is little knowledge of how they affect habitat resources and biotic assemblages in river reaches (Warfe et al., 2011). Furthermore, although the importance of natural flow variability in distributing wood in rivers is well-appreciated (Tockner et al., 2000), it is not well understood how the strong seasonality and high interannual variability in peak wet season flows might alter the dynamics and ecological role of river wood in tropical river systems. The fact that Australia's northern rivers have relatively intact flow regimes (Stein et al., 2002) and riparian zones (Woinarski et al., 2007) means they provide a good opportunity to compare wood dynamics with those in temperate zones, and address outstanding questions on the delivery and turnover of in-stream wood (Naiman et al., 2005) and the implications for the provision of aquatic habitat.

The objectives of this study were two-fold. First, to determine the physical characteristics and spatial distribution of aggregations of in-stream wood on two rivers in the Daly River catchment, and estimate the movement and turnover of in-stream wood after the large wet season flows experienced by these rivers. Second, to test the hypothesis that aggregations of in-stream wood are favoured habitat of some fish species and will therefore affect the structure of fish communities in the river. Collectively these results will provide information on the relative persistence of in-stream habitat after large wet season flows, and thus its 
River wood and fish habitat

susceptibility to flow alterations, and thereby contribute to our understanding of the ecological role of in-stream wood in wet-dry tropical rivers.

Methods

Site description

The Daly River catchment is located in the Northern Territory, Australia (Fig. 1). Its largest tributary is the Katherine River, and both rivers have a flow regime characteristic of Australia's wet-dry tropics with predictable and large wet season flows and high interannual variability (Kennard et al., 2010). Flow characteristics were derived for both rivers from 48year daily time series obtained from gauging stations (Dept. Natural Resources, Environment, The Arts and Sport, Northern Territory of Australia; Fig. 1). The Daly River (at the gauging station) has a mean annual discharge of $\sim 61,000 \mathrm{~m}^{3} \mathrm{~s}^{-1}$, and the Katherine River of $\sim 25,000$ $\mathrm{m}^{3} \mathrm{~s}^{-1}$ (Fig. 2), reflecting their catchment areas of $\sim 40,000 \mathrm{~km}^{2}$ and $\sim 10,000 \mathrm{~km}^{2}$, respectively. Both rivers experience most of their discharge (>97\%) during the summer wet season (November to April), but unlike many other rivers of northern Australia, they are perennial, with baseflows supplemented by groundwater and continuing through the winter dry season months (May to October; Kennard et al., 2010). Total discharge over the 20082009 wet season was $\sim 102,000$ and $\sim 36,000 \mathrm{~m}^{3} / \mathrm{s}^{-1}$ for the Daly and Katherine Rivers (respectively), which was $72 \%$ and $44 \%$ greater than the long-term average for each river.

The Daly and Katherine rivers are sand-bed rivers with occasional rock bars and generally steep banks rising 15-20 m above the river bed (Wasson et al., 2010) and comprising a series of benches created by wet season flows, and interspersed with areas of groundwater seepage during the dry season (Erskine et al., 2003). This results in a riparian forest on the banks exhibiting distinct vertical zonation from the river bed across the benches to the levee crest of the floodplain (Lamontagne et al., 2005). The riparian vegetation of the bank slopes are generally dominated by the tree species Melaleuca argentea, M. leucadendra, Corymbia bella, Eucalyptus camaldulensis, Cathormion umbellatum, Nauclea orientalis and Casuarina cunninghamiana, with M. argentea and M. leucadendra most common along the lower banks. 
River wood and fish habitat

Wood data collection

The spatial distribution of in-stream wood was surveyed at two sites, one on the Daly River $\left(14.0708^{\circ} \mathrm{S}, 131.3521^{\circ} \mathrm{E}\right)$, and one on the Katherine River $\left(14.5479^{\circ} \mathrm{S}, 132.1301^{\circ} \mathrm{E}\right.$; Fig. 1). Sites were a subset of sites from a larger project investigating relationships between flows and fish assemblage structure (B.J. Pusey and M.J. Kennard, unpubl. data), and were selected on the basis of being representative of both the Daly and Katherine Rivers according to remotely-sensed data and field observations. The Daly River site was a large channel (mean $60 \mathrm{~m}$ base flow width) and wider than the maximum length of all in-stream wood, while the Katherine River channel was narrower (mean 20 m width) but still wider than most in-stream wood . Approximately $2 \mathrm{~km}$ of river was surveyed at each site during the late dry season (November 2008 and October 2009), when water levels were at their lowest, to compare the spatial distribution of in-stream wood before and after the 2008-2009 wet season.

The minimum diameter measured of the largest piece within an aggregation was $>5 \mathrm{~cm}$ : smaller pieces were not surveyed. Surveys were conducted from a boat and the following characteristics recorded: GPS position, orientation in relation to the river bank $\left(0^{\circ}\right.$ (i.e. parallel to the river bank), $\left\langle 45^{\circ},>45^{\circ}, 90^{\circ}\right.$ ), diameter and length of the largest piece (as an indicator of in-stream wood size), and the "type" of in-stream wood aggregation. We adapted a classification based on the mechanism of formation and core material of in-stream wood from typologies developed for river wood in the Pacific north-west USA (Abbey and Montgomery, 2003) and the Sabie River in South Africa (Pettit et al., 2006). In-stream wood aggregations were classified as structures present in situ after fluvial disturbance: either a standing tree (live or dead) around which in-stream wood collected, or a fallen tree which had been pushed over (but not moved downstream) by floodwaters and had accumulated additional wood. Alternatively, river wood was classified as structures which had been generated or transported by fluvial disturbance: either a key piece which was a large dead log or tree usually including the root wad and accumulated wood, a single piece with no accumulated wood, or wrack which comprised piles of smaller wood and organic material with no core piece. A photograph of each recorded in-stream wood aggregation was taken and used in combination with the GPS coordinates to match in-stream wood between surveys. i.e. before and after the 2008-2009 wet season. Following the second (October 2009) survey, the photographs were also used to categorise in-stream wood into five age classes: 1) newly recruited trees with leaves, bark and fine twigs; 2) recent recruits with small branches and 
River wood and fish habitat

some bark; 3) mature recruits with predominantly large branches and little bark; 4) old recruits with water sculpted trunk and no branches; and 5) mixed ages.

Fish data collection

Fish assemblages and habitat characteristics were surveyed at four sites on the Daly River and two sites on the Katherine River (Fig. 1) during the late dry season (October) of 2006, 2007 and 2008, respectively. These fish assemblage data were part of an existing project investigating relationships between flows and fish assemblage structure (B.J. Pusey and M.J. Kennard, unpubl. data) and coincided with the in-stream wood survey in 2008.

A detailed description of fish and habitat sampling methods is available in Stewart-Koster et al., 2011 and Chan et al., 2012) and is briefly summarised here. Within each sampling site (500-1000 m reach length), fish assemblages were sampled at multiple discrete locations (electrofishing shots) using a boat-mounted, generator-powered electrofishing unit (Engineering Technical Services Model MBS-2DHP-SRC with pulsed DC current). These samples are hereafter termed electrofishing 'shots' with each shot fixed to five minutes duration (elapsed time) and averaging $110 \mathrm{~m}$ river length. Water conductivities varied widely among study sites (50-600 $\mathrm{ms} \mathrm{cm}^{-1}$ ) so electrofisher output settings were adjusted to maximize efficiency at each site but with the minimum power required to stun fishes (pulsed DC current, $<250$ pulses s $^{-1},<500 \mathrm{~V},<25 \%$ duty cycle, maximum $\left.35 \mathrm{~A}\right)$. Usually, 15 electrofishing shots were undertaken at each site, with the intent of sampling the full range of habitat types present (e.g. riffles, runs, pools, macrophyte beds, stretches of mid-channel open water, undercut banks and woody debris piles). At the completion of each electrofishing shot, fishes were identified to species level, measured (standard length) and returned alive to the approximate point of capture. Fish catches were standardized to catch per unit effort for subsequent analyses (total number of individuals per electrofishing shot).

\section{Environmental data collection}

A range of hydraulic and microhabitat parameters were measured or estimated for each electrofishing shot location. The mean of five replicate measurements of total water depth (graduated pole) and average water velocity (Swoffer Instruments Inc. water velocity meter) were taken from random locations within the shot area. Visual estimates were also taken of the aerial proportion of the shot area covered by different substrate types (i.e. mud, sand, 
River wood and fish habitat

cobble, rock), submerged or emergent macrophytes and physical structures (i.e. wood debris, leaf litter, root mats and bank undercuts).

Data analysis

All data used in statistical tests were transformed $(\log (x+1))$ where necessary to meet criteria of normality and homogeneity of variance. Differences in the diameter of the largest piece of wood within aggregate types between the Daly and Katherine reaches were tested using a ttest. Differences in the size and abundance between types in each river were tested using a one-way ANOVA and any significant differences between types were further tested by the Fisher's PLSD post-hoc test.

Fish assemblage data were analysed using non-parametric routines in PRIMER Version 6.1.5 (Clarke and Gorley, 2006) To explore which group of habitat variables best explained the spatial variation observed in fish assemblage structure, a variation partitioning technique, distance-based (Euclidean) redundancy analysis (dbRDA), was performed using the DistLM and dbRDA routines in PERMANOVA+ (Legendre and Anderson, 1999). A Bray-Curtis similarity matrix of the fish assemblage data was used for this analysis, and a step-wise selection of the habitat-related variables (average water depth, average velocity, channel width, percentage root mass, cobble, emergent vegetation, leaf litter, bank undercut and in-stream wood) was conducted using the adjusted $\mathrm{R}^{2}$ selection criterion and a permutation test of significance (Legendre and Anderson, 1999). Ordination of fish assemblages in dbRDA space was also conducted to visualize the effects of habitat variables. The RELATE procedure (a non-parametric form of the Mantel test, Clarke and Gorley, 2006) was also used to test the significance of relationships between fish species composition and environmental variables, and ANOSIM (non-parametric ANOVA) was used to look at differences in fish communities between years.

Results 
River wood and fish habitat

37.5 pieces $\mathrm{km}^{-1}$ in October 2009. The distribution of in-stream wood was uniformly positioned throughout both reaches (Fig. 3) with the in-stream wood fairly evenly-distributed adjacent to either river bank (45\% left bank (looking downstream) and 35\% on the right). The largest proportion $(48 \%)$ of in-stream wood pieces were orientated at $<45$ degrees to the direction of flow at both sites, with $23 \%>45$ degrees from the bank and the rest of the pieces either parallel $\left(0^{\circ}\right)$ or oriented at ninety degrees to the bank.

In-stream wood types

During the initial survey (November 2008) of the Daly reach, the most common types of instream wood recorded were the single pieces (34\%), followed by key pieces (30\%), with wrack the least common (Fig. 4a). At the Katherine reach, fallen trees (36\%) and key pieces (34\%) were the most common types while single pieces were least common at this site (Fig. 4a). At the Daly reach there appeared to be recruitment of trees into the river with a large increase (by three times) in the number of in situ, fallen tree in-stream wood types from one wet season to the next. At the Katherine River reach there was considerable movement of instream wood with the number of the transported wrack doubling from the 2008 to 2009 survey but with $62 \%$ fewer key pieces in 2009 (Fig. 4a).

ARW size and age

The diameter of the largest piece of in-stream wood was significantly larger at the Daly site than at the Katherine site $\left(\mathrm{t}_{196}=5.67, \mathrm{p}<0.001\right)$ with a mean diameter of the largest piece within in-stream wood aggregations of 470mm (range $90-1200 \mathrm{~mm}$ ) for the Daly site and $282 \mathrm{~mm}$ (range $40-700 \mathrm{~mm}$ ) at the Katherine site (Fig. 4b). The diameter of in-stream wood aggregation types was significantly different $\left(\mathrm{F}_{3,192}=33.6, \mathrm{p}<0.001\right)$, with key pieces $(602 \pm$ $30 \mathrm{~mm}$; mean $\pm \mathrm{SE})$ significantly larger than the other types. Wrack $(155 \pm 21 \mathrm{~mm})$ and single piece (mean dia. $272 \pm 67 \mathrm{~mm}$ ) ARW were also significantly smaller than the standing tree $(428 \pm 72 \mathrm{~mm})$ and fallen tree $(459 \pm 91 \mathrm{~mm})$ in-stream wood aggregations.

The frequency distribution of age classes was similar at both sites with most in-stream wood in the middle age classes with fewer in the youngest (Class 1) and oldest class (Class 4) (Fig. 4c). This indicates continual recruitment and loss of wood from both sites over time. There was no significant difference in the diameters of the in-stream wood aggregations for the different age classes $\left(\mathrm{F}_{3,182}=1.29, \mathrm{p}=0.27\right)$. 
River wood and fish habitat

\section{Movement of ARW}

At the Daly River site, where 2008-09 wet season discharge was 72\% higher than average, $51 \%$ of in-stream wood aggregations were not recorded in the same place between 2008 and 2009, and 44\% of in-stream wood aggregations had moved at the Katherine site (Fig. 4a), where 2008-09 discharge was $44 \%$ above average. At both study sites, the size of in-stream wood aggregations that were recorded in the same place between years was significantly larger than for pieces that had moved out of the reach $\left(t_{196}=4.01, p<0.001\right)$, with in-stream wood aggregations in smaller size classes more commonly moving over the wet season (Fig. 5a). There were differences between in-stream wood aggregation types in the proportion of each that had moved position, although this did not appear to be affected by the size of the different types (Fig. 5b). Key pieces had the largest diameter of any type, but had a greater proportion that had moved over the wet season in comparison to the smaller fallen tree and standing tree in-stream wood aggregations; standing trees were the least likely type to have moved over the 2008-09 wet season (Fig. 5b). The in-stream wood aggregations that were recorded in the same place, from one year to the next, did not always maintain the same structure however, as wood was added or removed.

Wood as fish habitat

There were no significant correlations between cover of in-stream wood within a shot and species richness $\left(r^{2}=0.057, p=0.08\right)$, fish abundance $\left(r^{2}=0.025, p=0.165\right)$ or species diversity $(H),\left(r^{2}=0.03, p=0.06\right)$. However, many of the habitat variables measured, including proportion of in-stream wood, showed a significant relationship with fish assemblage composition (Table 1). At the reach scale (individual shots) the dbRDA indicated that the highest correlation $\left(r^{2}=0.1789\right)$ was with all nine habitat variables included, with the highest F-values for marginal tests for stream width, proportion of in-stream wood, and water depth (Table 1). Ordination of sites (Fig. 6) illustrated the environmental variables, stream width, proportion of in-stream wood, and average water depth were most influential in separating shots (Table 1, Fig. 6). Along with in-stream wood cover, root mat cover and bank undercut were negatively correlated with dbRDA1 $(r=0.463$ and 0.434 and -0.431 respectively), while stream width $(\mathrm{r}=0.571)$ was positively correlated with dbRDA axis 1 . Stream average depth $(r=0.671)$, in-stream wood $(r=0.411)$ and stream width $(0.432)$ influenced the separation of shots along dbRDA axis 2 (Fig. 6). The RELATE matrix similarity test also indicated a significant relationship between fish species composition and in-stream wood cover $(\rho=0.144, p<0.001)$ as well as for other environmental variables 
River wood and fish habitat

stream width $(\rho=0.214 \mathrm{p}<0.001)$ and average depth $(\rho=0.139 \mathrm{p}<0.001)$, but not for the other environmental variables (all $\rho<0.041 \mathrm{p}>0.06$ ).

Of the 34 fish taxa sampled $62 \%$ had higher abundance in shots with 10-30 \% in-stream wood cover ( $n=81$ shots) while $38 \%$ of fish taxa had higher abundance where there was $<10 \% \operatorname{wood}(\mathrm{n}=100)$. Interestingly no fish taxa had higher abundance in shots with $>30 \%$ in-stream wood cover $(n=46)$. To look at particular species that may be associated with instream wood we superimposed species abundance data for species on the shot scale dbRDA ordination (Fig. 6). Particular fish species that were most abundant in shots with a $10-30 \%$ wood cover included 220\% higher abundance for rainbowfish (Melanotaenia australis), $880 \%$ higher for adult archer fish (Toxotes chartareus), and both juvenile (118\% higher) and adult (60\% higher) barramundi (Lates calcarifer) (Fig. 6). Some species such as the sooty grunter (Hephaestus fuliginosus) showed different associations depending on life stage, with adults having higher abundance (900\%) with 10 - 30\% wood cover but juveniles with $50 \%$ more individuals in shots with $<10 \%$ wood cover (Fig. 6). Several species such as spangled perch (Leiopotherapon unicolor) showed no particular association with river wood coverage (Fig. 6).

The ANOSIM procedure indicated that there was a small significant difference in fish species composition between sampling years 2005 and $2007(\mathrm{R}=0.094, \mathrm{p}=0.04)$. However, the dbRDA for each year indicated that the same environmental variables were most influential on fish assemblages across years (i.e. stream width, depth, in-stream wood, and bank undercut).

At the larger site- scale (average of 10-15 shots per site) there were no significant correlations between cover of in-stream wood within a site and species richness $\left(r^{2}=0.166\right.$, $\mathrm{p}=0.116)$, fish abundance $\left(\mathrm{r}^{2}=0.005, \mathrm{p}=0.58\right)$ or species diversity $(\mathrm{H}),\left(\mathrm{r}^{2}=0.003, \mathrm{p}=\right.$ 0.44). At the site-scale, dbRDA indicated the relationship was similar to the smaller shot scale, with a significant relationship between in-stream wood cover and fish assemblage structure $\left(\mathrm{F}_{31}=2.29, \mathrm{p}=0.013\right)$, and the other environmental variables of stream width $\left(\mathrm{F}_{31}\right.$ $=3.65, \mathrm{p}=0.001)$, depth $\left(\mathrm{F}_{31}=2.49, \mathrm{p}=0.011\right)$, and bank undercut $\left(\mathrm{F}_{31}=2.38, \mathrm{p}=0.009\right)$ having a stronger influence on fish assemblage structure. 
River wood and fish habitat

\section{Discussion}

Differences in the structure and composition of in-stream wood aggregations in the Daly River catchment described in this study will likely contribute significantly to habitat heterogeneity at both the reach and site scales. In-stream wood is particularly important in downstream sections of sand bed rivers, such as the Daly and Katherine rivers, where there is often a lack of stable substrate for primary production and habitat for many animals (Crook and Robertson, 1999; Gurnell et al., 2000; Crook et al., 2001; Pusey and Arthington, 2003). Our findings show that there is considerable in-stream wood in the Daly River and that this wood can create important habitat for some fish species and influences overall fish assemblage structure. We suggest that the type, abundance and position of these in-stream wood aggregations are influential in providing structural and habitat complexity, as has been found in other river environments (Crook et al., 2001; Gurnell et al., 2005; Naiman et al., 2005; Pettit and Naiman, 2005, Schneider and Winemiller, 2008).

We found densities of in-stream wood aggregations of between 27 - 78 pieces $\mathrm{km}^{-1}$ in the reaches surveyed. Wood surveys in other river systems of similar size in Australia and elsewhere report similar wood densities. In south-eastern Australia these range from 15 - 46

pieces $\mathrm{km}^{-1}$ in the Murray River main channel and $23-64$ pieces $\mathrm{km}^{-1}$ in the medium-sized Goulburn River (Anderson and Morrison, 1988), and 121 pieces $\mathrm{km}^{-1}$ in the smaller Thompson River (Gippel et al., 1996). In large mid-continental rivers of the USA, densities of $26-80$ pieces $\mathrm{km}^{-1}$ are reported by Angradi et al. (2010), who suggested that wood density was related to channel size and high flows, both of which create a greater capacity for the transport of wood (Bilby and Ward, 1989). Differences in in-stream wood density between the two rivers we surveyed are most likely related to both the higher density of riparian forest and higher discharge, creating greater erosion forces, in the Daly River compared to the Katherine River. Density of the riparian and floodplain forest is an important factor in the subsequent density of in-stream wood (Gurnell et al., 2002).

The age class structure of in-stream wood suggested continual recruitment of pieces into the Daly and Katherine rivers. This recruitment has resulted from the combination of dense riparian forest, steep banks and frequently large, high energy wet season flows. High annual flows scour the bank soil around riparian trees, which subsequently topple into the river, and recent research indicates that the amount of soil and vegetation entering the river during wet 
River wood and fish habitat

season flows has increased since 1975, due to climatic, and thus hydrological, change (Wasson et al., 2010). Added to this are numerous groundwater seepage points along the Daly River that cause bank slumping, undermining riparian trees (Wasson et al., 2010), and also contributing to continual recruitment of trees into the river each year. The high proportion of in-stream wood that moved during the study period may reflect the higher than average flows experienced for both the Daly and Katherine river sites for the 2008/9 wet season ( $>50 \%$ higher). These flows appear to result in new wood entering the study reaches, most likely from upstream via significant re-working of existing in-stream wood. Frequent lateral channel movement has been reported to be responsible for the recruitment and redistribution of river wood in dense temperate rainforest river valleys in the Pacific North West USA (Latterell et al., 2006), and in wet sclerophyll river valleys in south-eastern Australia (Brooks et al., 2003). Flows of sufficient magnitude may also result in the episodic recruitment of wood into the river, and there is anecdotal evidence that wood was not as abundant in the Daly River prior to a large flood event in the 2004/5 wet season (B. Pusey, pers. obs.), which delivered flows $75 \%$ greater than the mean annual wet season flow.

The most common trees that constituted the majority of the in-stream wood included the trunks and branches of Melaleuca leucadendra, M. argentea, Eucalyptus camaldulensis, and Casuarina cunninghamiana. These trees are not buoyant and have complex architecture, with large side branches (Fig. 7). They are therefore, at least initially, not likely to be transported far downstream and generally remain close to where they had fallen. However, over time, pieces will break off and be moved around the river in subsequent flows to join or form other in-stream wood aggregations. Some wood also becomes buried or is moved large distances downstream. It is the formation of these aggregations of wood that we suggest is important for the creation of habitat for fish and other biota.

For the Daly River, patterns of wood accumulation are largely controlled by the ability of the wood to be moved, with $>40 \%$ in-stream wood aggregations (particularly key pieces, single pieces and wrack) having been entrained by high flows and deposited downstream of the site of recruitment. However, unlike in other systems, there appeared no pattern in the deposition of wood at particular sites at the measured scale in the present study. In North American temperate rivers, the pattern of wood distribution can be strongly influenced by the spatial distribution of source areas (the distance wood was transported relative to the distance between source areas and the presence of trapping sites (Swanson, 2003)), and on the Murray 
River wood and fish habitat

River in south-eastern Australia, in-stream wood is often associated with meander banks (Koehn et al., 2004). Accumulation and retention of in-stream wood aggregations is related to size of the river channel and geomorphic pattern, with meandering channels able to retain more wood than braided channels (Piégay and Gurnell, 1997). The pattern of in-stream wood distribution is influenced to a large extent by the scale at which it is measured, with in-stream wood uniformly distributed at the reach scale but strongly associated with eroding sites and meander development at the sub-reach scale (Hughes and Thoms, 2002; Parsons and Thoms, 2007). Pettit et al. (2006) further suggested that in situ structures such as standing trees and exposed bedrock were important determinants of wood accumulation for a perennial bedrock river in sub-tropical Africa. It appears the relatively uniform availability of source material, relative scarcity of trapping sites, and large discharges in the Daly and Katherine rivers, supports the finding that where there is long-distance transport of wood that is likely to be randomly arranged (Piégay and Gurnell, 1997).

There are likely to be general processes of in-stream wood dynamics, described elsewhere in temperate and semi-arid rivers (Latterell and Naiman, 2007; Pettit et al., 2006), that apply similarly to the Daly River. For example, after a fluvial disturbance, in-stream wood is deposited on the channel floor and can become partially buried under sediment or transported downstream where it can provide a short- to medium-term structure for primary and secondary productivity within the river (e.g. Pettit et al., 2006). How long this river wood remains an ecological asset is difficult to assess as the lifespan of individual in-stream wood aggregations depends to a large extent on the durability of key pieces, whereas the character of the in-stream wood aggregations is more likely to depend on the accumulation or loss of smaller pieces (Gippel et al., 1996; Manners and Doyle, 2008).

Due to strong relationships among environment variables and the relatively low proportion of variability in fish assemblage data explained by the environmental variables measured, the result of our hypothesis that aggregations of in-stream wood are favoured habitat of some fish species is inconclusive. However, there is evidence that in-stream wood in the Daly and Katherine rivers is important for fish assemblage structure and for particular species at the river reach $(100 \mathrm{~m})$ and site $(1 \mathrm{~km})$ scales. Along with other environmental factors such as stream width and depth, in-stream wood was the most influential habitat variable explaining species assemblage structure, more so than other potential habitats such as rootmats and bank undercuts. Also, the majority of fish were more abundant where wood was present. 
River wood and fish habitat

Many studies in varying climates have shown strong associations between fish abundance and diversity and in-stream wood (e.g. Quinn and Peterson, 1996; Jepsen et al., 1997; Crook et al., 2001; Mossop and Bradford, 2004; Boys and Thoms 2006; Schneider and Winemiller, 2008). Fish use of in-stream wood may be related to age and architecture of the wood. Recently recruited in-stream wood is less stable and will not have had time for the establishment of plants and invertebrates that may attract fish but may be used by more mobile fish as temporary relief from currents or from predators (Pusey and Arthington 2003). Arrington et al. (2005) suggests that fish use of newly deposited wood is based on dispersal to and colonisation of a site, but for older established wood, the characteristics of the habitat are more important in determining the fish assemblage structure. The form, contents and dynamics of in-stream wood aggregations are all important in determining their use by fish. For example, small fish may use the dense smaller diameter branches for feeding and cover, while larger fish may use the deeper scour pools that form at the base of the root wad on large key pieces and aggregations. The large predatory barramundi (Lates calcarifer) was associated with in-stream wood in this study and uses this habitat as cover to ambush prey (Pusey et al., 2004). Strong associations with barramundi and in-stream wood have also been shown in rivers in the Australian wet tropics (Rayner et al. 2008). Indeed, two fish species that showed strong associations with wood in the present study, barramundi and adult sooty grunter (Hephasetus fuliginosus), are both key species for recreational, commercial and customary indigenous fisheries in the Northern Territory and contribute to the region's economy (Warfe et al., 2011). This study provides some evidence of the importance of instream wood for fish in these tropical rivers but further experimental work is needed to confirm the importance and differential use of in-stream wood by different fish species and age classes suggested in the present study.

In many parts of the world, in-stream wood is routinely removed from lowland rivers (Gurnell et al., 2000; Montgomery and Piegay, 2003; Scealy et al., 2007) for, among other reasons, flood mitigation and improving channel navigation. This study has indicated the importance of flows in the wet season for both the recruitment of wood into the river and the transport of wood within the river. Dry season flows are also likely to be important for the maintenance of refugial habitat at low water levels. These effects have clear implications for river environmental flow considerations, for example, a reduction of wet season flows may reduce habitat turnover and thereby affect fish assemblage structure. As we address these knowledge gaps on in-stream wood dynamics and its ecological importance in tropical rivers 
River wood and fish habitat

there is potential for this information to feed into the development of flow-habitat-ecology relationship models.

Acknowledgements

The authors gratefully acknowledge the Wagiman and Jawoyn communities in the Northern Territory for access to study sites. For assistance in the field we thank Quentin Allsop, Ian Dixon, Poncie Kurnoth, Peter Kyne, Anne Pettit, Dave Wilson and Alex Wood. We thank Professor R. J. Naiman for his constructive and insightful comments on an earlier draft of this manuscript. Funding for this project was provided by the Tropical Rivers and Coastal Knowledge (TRaCK) research programme which receives major funding for its research through the Australian Government's Commonwealth Environment Research Facilities initiative, the Australian Government's Raising National Water Standards Programme, the Fisheries Research and Development Corporation, the National Environmental Research Program and the Queensland Government's Smart State Innovation Fund.

\section{References}

Abbe TB, Montgomery DR. 2003. Patterns and processes of wood debris accumulation in the Queets River basin, Washington. Geomorphology 51: 81-107

Anderson JR, Morrison AK. 1988. A study of the native fish habitat in the Goulburn River, Shepparton - impact of a proposal to operate a paddle steamer. Arthur Ryah Institute for Environmental Research, Technical Report Series No. 68, Department of Conservation and Environment, Heidelberg, Victoria, Australia.

Angradi TR, Taylor DL, Jicha TM, Bolgrien DW, Pearson MS, Hill BH. 2010. Littoral and shoreline wood in mid-continent great rivers (USA). River Research and Applications 26: 261-278.

Arrington DA, Winemiller KO. 2006. Habitat affinity, the seasonal flood pulse, and community assembly in the littoral zone of a Neotropical floodplain river. Journal of the North American Benthological Society 25: 126-141.

Arrington DA, Winemiller KO, Layman CA. 2005. Community assembly at the patch scale in a species rich tropical river. Oecologia 144: 157-167. 
River wood and fish habitat

Bilby RE, Likens GE. 1980. Importance of organic debris dams in the structure and function of stream ecosystems. Ecology 61: 1107-1113.

Bilby RE, Ward JW. 1989. Characteristics and function of woody debris with increasing size of streams in western Washington. Transactions of the American Fisheries Society 118: 368-378.

Bond NR, Lake PS. 2003. Characterising fish-habitat associations in streams as the first step in ecological restoration. Austral Ecology 28: 611-621.

Boys CA, Thoms MC. (2006). A Large-scale, Hierarchical Approach for Assessing Habitat Associations of Fish Assemblages in Large Dryland Rivers. Hydrobiologia 572: 11-31.

Brooks AP, Brierley GJ, Millar RG. 2003. The long-term control of vegetation and woody debris on channel and flood-plain evolution: insights from a paired catchment study in southeastern Australia. Geomorphology 51: 7-29.

Cadol D, Wohl E, Goode JR, Jaeger KL. 2009. Wood distribution in neotropical forested headwater streams of La Selva, Costa Rica. Earth Surface Processes and Landforms 34: 1198-1215.

Chan T, Hart B, Kennard MJ, Pusey BJ, Shenton W, Douglas M, Valentine E, Patel S. 2012. Bayesian network models for environmental flow decision-making in the Daly River, Northern Territory, Australia. River Research and Applications. 28: 283-301.

Clarke KR, Gorley RN. 2006. PRIMER v6: user manual/tutorial. Primer-E., Plymouth, UK.

Crook DA, Robertson AI. 1999, Relationships between riverine fish and woody debris: implications for lowland rivers. Marine and Freshwater Research 50: 941-953.

Crook DA, Robertson AI, King AJ, Humphries P. (2001). The influence of spatial scale and habitat arrangement on diel patterns of habitat use by two lowland river fishes. Oecologia 129: 525-33.

Davies PM, Storey AW. 1998. Large woody debris is important habitat in rivers. Western Wildlife 2: 14-15.

Entrekin SA, Tank JL, Rosi-Marshall EJ, Hoellein TJ, Lamberti GA. 2009. Response of secondary production by macroinvertebrates to large wood addition in three Michigan streams. Freshwater Biology 54: 1741-1758.

Erskine-WD, Begg GW, Jolly P, Georges A, O'Grady A, Eamus D, Rea N, Dostine P, Townsend S, Padovan A. 2003. Recommended environmental water requirements for the Daly River, Northern Territory, based on ecological, hydrological and biological principles. National River Health Programme, Environmental Flows Initiative, Technical Report 4, Supervising Scientist, Canberra, Australia. 
River wood and fish habitat

Finlayson CM. 2005. Plant ecology of Australia's tropical floodplain wetlands: A review. Annals of Botany 96: 541-555.

Fremier AK, Seo JI, Nakamura F. 2009. Watershed controls on the export of large wood from stream corridors. Geomorphology 117: 33-43.

Gippel CJ, Finlayson BL, O’Neill IC. (1996). Distribution and hydraulic significance of large woody debris in a lowland Australian river. Hydrobiologia 318: 179-194.

Gregory SV, Boyer K, Gurnell A. Eds. 2003 The ecology and management of wood in world rivers. American Fisheries Society, Bethesda, USA.

Gurnell AM, Petts GE, Hannah DM, Smith BPG, Edwards PJ, Kollmann J, Ward JV, Tockner K. 2000. Wood storage within the active zone of a large European gravel-bed river. Geomorphology 34: 55-72.

Gurnell A.M., Piegay H., Swanson F.J. and Gregory S.V. (2002) Large wood and fluvial processes. Freshwater Biology, 47, 601-619.

Gurnell A, Tockner K, Edwards P, Petts G. 2005. Effects of deposited wood on biocomplexity of river corridors. Frontiers in Ecology and the Environment 3: 377-382.

Hughes V, Thoms MC. 2002. Associations between channel morphology and large woody debris in a lowland river. In The structure, function and management implications of fluvial sedimentary systems. Proceedings of an International Symposium, IAHS

Jepsen JB, Winemiller KO, Taphorn DC. 1997. Temporal patterns of resource portioning among Cichla species in a Venezuelan blackwater river. Journal of Fish Biology 51: 1085-1108.

Keller EA, Swanson FJ. 1979. Effects of large organic material on channel form and fluvial processes. Earth Surface Processes and Landforms, 4, 361-380.

Kennard MJ, Pusey BJ, Olden JD, Mackay SJ, Stein JL, Marsh N. 2010. Classification of natural flow regimes in Australia to support environmental flow management. Freshwater Biology 55: 171-193.

Koehn JD, Nicol SJ, Fairbrother PS. (2004). Spatial arrangement and physical characteristics of structural woody habitat in a lowland river in south-eastern Australia. Aquatic Conservation: Marine and Freshwater Ecosystems 14: 457-464.

Lamontagne S, Cook PG, O’Grady A, Eamus D. 2005.. Groundwater use by vegetation in a tropical savanna riparian zone (Daly River, Australia). Journal of Hydrology 310: 280293. 
River wood and fish habitat

Latterell JJ, Naiman RJ, Fransen BR, Bisson PA. 2003. Physical constraints on trout (Oncorhynchus spp.) distribution in the Cascade Mountains: a comparison of logged and unlogged streams. Canadian Journal of Fish and Aquatic Sciences 60: 1007-1017.

Latterell JJ, Bechtold JS, Naiman RJ, O'Keefe TC, Van Pelt R. 2006. Dynamic patch mosaics and channel movement in an unconfined river valley of the Olympic Mountains. Freshwater Biology 51:523-544.

Latterell JJ, Naiman RJ. 2007. Sources and dynamics of large logs in a temperate floodplain river. Ecological Applications 17: 1127-1141.

Lassettre NS, Piegay H, Dufour S, Rollet AJ. 2008. Decadal changes in distribution and frequency of wood in a free meandering river, the Ain River, France. Earth Surface Processes and Landforms 33: 1098-1112.

Legendre P, Anderson MJ. 1999. Distance-based redundancy analysis: testing multispecies responses in multifactorial ecological experiments. Ecological Monographs 69: 1-24.

Lester RE, Wright W, Jones-Lennon M. (2007). Does adding wood to agricultural streams enhance biodiversity? An experimental approach. Marine and Freshwater Research 58: 687-698.

Lester RE, Boulton AJ. (2008). Rehabilitating Agricultural Streams in Australia with Wood: A Review. Environmental Management 42: 310-326.

Lewis WM. 2008. Physical and chemical features of tropical flowing waters. In: Tropical Stream Ecology Dudgeon D (ed), pp. 2-23. Elsevier, London, U.K.

Lienkaemper GW, Swanson FJ. 1987. Dynamics of large woody debris in streams in oldgrowth Douglas fir forests. Canadian Journal of Forest Research 17: 150-156.

Manners RB, Doyle MW. 2008. A mechanistic model of woody debris jam evolution and its application to wood-based restoration and management. River Research and Applications 24: 1104-1123.

Montgomery DR, Piegay H. 2003. Wood in rivers: interactions with channel morphology and processes. Geomorphology 51: 1-5.

Mossop B, Bradford MJ. 2004. Importance of large woody debris for juvenile Chinook salmon habitat in small boreal forest streams in the upper Yukon River basin, Canada. Canadian Journal of Forest Research 34: 1955-1966.

Naiman RJ, Decamps H, McClain ME. 2005. Riparia: Ecology, conservation and management of streamside communities. Elsevier Academic Press, Boston, USA.

Naiman RJ, Latterell JJ, Pettit NE, Olden JD. 2008. Flow variability and biophysical vitality of river systems. Comptes Rendus Geosciences, 340, 629-643. 
River wood and fish habitat

Parsons M, Thoms MC. 2007: Hierarchical patterns of physical-biological associations in river ecosystems. Geomorphology 89: 127-146.

Pettit NE, Naiman RJ. 2005. Flood-deposited wood debris and its contribution to heterogeneity and regeneration in a semi-arid riparian landscape. Oecologia 145: 434444.

Pettit NE, Latterell JJ, Naiman RJ. 2006. Formation, distribution and ecological consequences of flood-related wood debris piles in a bedrock confined river in semi-arid South Africa. River Research and Applications 22: 1097-1110.

Pettit NE, Bayliss P, Davies PM, Hamilton SK, Warfe DM, Bunn SE, Douglas MM. 2011. Seasonal contrasts in carbon resources and ecological processes on a tropical floodplain. Freshwater Biology 56: 1047-1064. doi:10.1111/j.1365-2427.2010.02544.x

Piegay H, Gurnell AM. 1997. Large woody debris and river geomorphological pattern: examples from S.E. France and S. England. Geomorphology 19: 99-116.

Pusey BJ, Arthington AH. 2003. Importance of the riparian zone to the conservation and management of freshwater fish: a review. Marine and Freshwater Research 54: 1-16.

Pusey BJ, Kennard MJ, Arthington AH. 2004. Freshwater Fishes of North-eastern Australia. 684 pp, CSIRO Publishing, Collingwood, Australia.

Quinn TP, Peterson NP. 1996. The influence of habitat complexity and fish size on overwinter survival and growth of individually marked juvenile coho salmon (Oncorhynchus kisutch) in Big Beef Creek, Washington. Canadian Journal of Fisheries and Aquatic Sciences 53: 1555-1564.

Rayner TS, Pusey BJ, Pearson RG. 2008. Seasonal flooding, instream habitat structure and fish assemblages in the Mulgrave River, north-east Queensland: towards a new conceptual framework for understanding fish-habitat dynamics in small tropical rivers. Marine and Freshwater Research 59: 97-116.

Scealy JA, Mika SJ, Boulton AJ. 2007. Aquatic macroinvertebrate communities on wood in an Australian lowland river: experimental assessment of the interactions of habitat, substrate complexity and retained organic matter. Marine and Freshwater Research 58: 153-165.

Schneider KN, Winemiller KO. 2008. Structural complexity of woody debris patches influences fish and macroinvertebrate species richness in a temperate floodplain-river system. Hydrobiologia 610: 235-244.

Smock LA, Metzler GM, Gladden JE. 1989. Role of debris dams in the structure and functioning of low gradient headwater streams. Ecology 70: 764-775. 
Stein, JL, Stein JA, Nix HA. 2002. Spatial analysis of anthropogenic river disturbance at regional and continental scales: identifying the wild rivers of Australia. Landscape and Urban Planning 60: 1-25.

Stewart-Koster B, Olden JD, Kennard MJ, Pusey BJ, Boone EL, Douglas M, Jackson S. 2011. Fish response to the temporal hierarchy of the natural flow regime in the Daly River, northern Australia. Journal of Fish Biology. 79: 1525-1544.

Swanson FJ. 2003. Wood in rivers: A landscape perspective. In The ecology and management of wood in world rivers. Gregory SV, Boyer KL, Gurnell A (eds), pp 299-313. American Fisheries Society, Bethesda, Maryland, USA.

Tockner K., Malard F, Ward JV. 2000. An extension of the flood pulse concept. Hydrological Processes 14: 2861-2883.

Warfe DM, Pettit NE, Davies PM, Pusey BJ, Hamilton SK, Bayliss P, Ward DP, Kennard MJ, Townsend S, Douglas MM, Burford MA, Finn M, Bunn SE, Halliday I. (2011) The wet-dry in the wet-dry tropics drives ecosystem structure and function of northern Australian rivers. Freshwater Biology. doi:10.1111/j.1365-2427.2011.02660.x

Wasson RJ, Furlonger L, Parry D, Pietsch T, Valentine E, Williams D. 2010. Sediment sources and channel dynamics, Daly River, Northern Australia. Geomorphology 114: 161-174.

Webb AA, Erskine WD. 2003. Distribution, recruitment and geomorphic significance of large woody debris in an alluvial forest stream: Tonghi Creek, south-eastern Australia. Geomorphology 51: 109-126.

Willis SC, Winemiller KO, Lopez-Fernandez H. 2005. Habitat structural complexity and morphological diversity of fish assemblages in a neotropical floodplain river. Oecologia 142: 284-295.

Woinarski J, Mackey B, Nix H, Traill B. 2007. The Nature of Northern Australia: natural values, ecological processes and future prospects. ANU E Press, The Australian National University, Canberra, Australia. 
River wood and fish habitat

Tables

Table 1: DISTLM marginal tests indicating the habitat variables affecting fish assemblage composition. Samples were collected from 313 shots at six main channel sites on the Daly and Katherine rivers in October (late dry season) 2006, 2007, 2008.

\begin{tabular}{llll}
\hline variable & SS & pseudo F & p \\
\hline stream width & 27774 & 9.75 & 0.001 \\
\% wood & 22248 & 7.73 & 0.001 \\
water depth & 20898 & 7.24 & 0.001 \\
Undercut & 20579 & 7.12 & 0.001 \\
\% root mat & 19907 & 6.88 & 0.001 \\
\% leaf litter & 10218 & 3.46 & 0.004 \\
water velocity & 10027 & 3.39 & 0.006 \\
$\%$ submerged veg & 5287 & 1.77 & 0.062 \\
\% cobble & 4200 & 1.41 & 0.179 \\
\hline
\end{tabular}




\section{Figure Captions}

Figure 1: Location of study sites in the Daly River catchment, in northern Australia (inset). Data on river wood were collected from two sites in October 2008 and November 2009 (designated by grey rectangles, not to scale); data on fish assemblages and habitat characteristics were collected from six sites in October 2006, 2007 and 2008 (designated by closed circles). River gauging stations from which hydrology data were used are located at two sites (designated by arrows).

Figure 2: Annual river discharges for the Daly and Katherine rivers over the years of record. Years of the study period (2006-2009) are indicated by arrows. Long term annual average discharge is indicated by dashed line.

Figure 3: Location of in-stream aggregated river wood in the surveys in November 2008 and October 2009 along a) Daly river at Oollo crossing, and b) Katherine River at Galloping Jacks.

Figure4: a) Number of different types of ARW at each site for each year. b) Age class distribution of aggregated river wood surveyed in October 2009 (1- new; 2 - recent; 3 mature; 4 - old; 5 - mixed ages).

Figure 5: Proportion of wood that has moved between surveys $(2008$ - 2009) for (a) ARW diameter size classes, and (b) the different ARW types (left hand vertical axis), with ARW types arranged in descending order of size from key piece to wrack (right hand vertical axis).

Figure 6: Ordination (dbRDA) of fish assemblage data for main channel sites sampled in October 2006, 2007, 2008 with proportion of wood for each shot indicated with <10\% wood cover (grey open circles), 10-30\% wood cover (light-grey inverted triangles), and $>30 \%$ wood cover (dark-grey squares). Vector plot indicates habitat variables with a statistically significant correlation ( $>0.35$ ) with the 2 axes. Bubble plots of the dbRDA ordination of fish community data with abundance of selected species and age classes superimposed on shots. Abundance of each fish species are represented by the relative size of the circles.

Figure 7: Key piece aggregation of in-stream wood on the Daly River, northern Australia illustrating the transport of large wood pieces downstream that, because of the large side branches lodge in the stream and then become in-stream features as the trap more wood. 
River wood and fish habitat

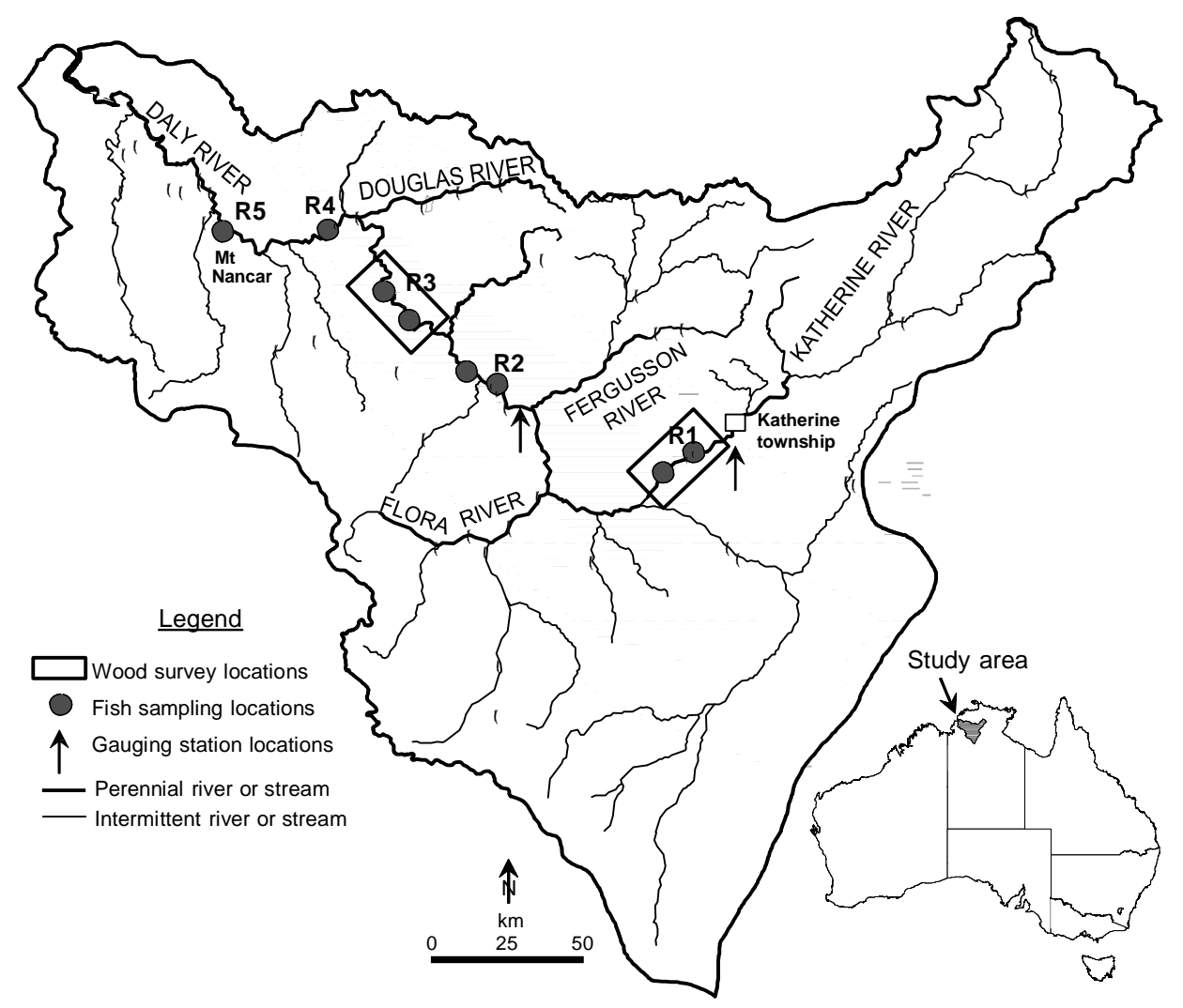

Figure 1. 


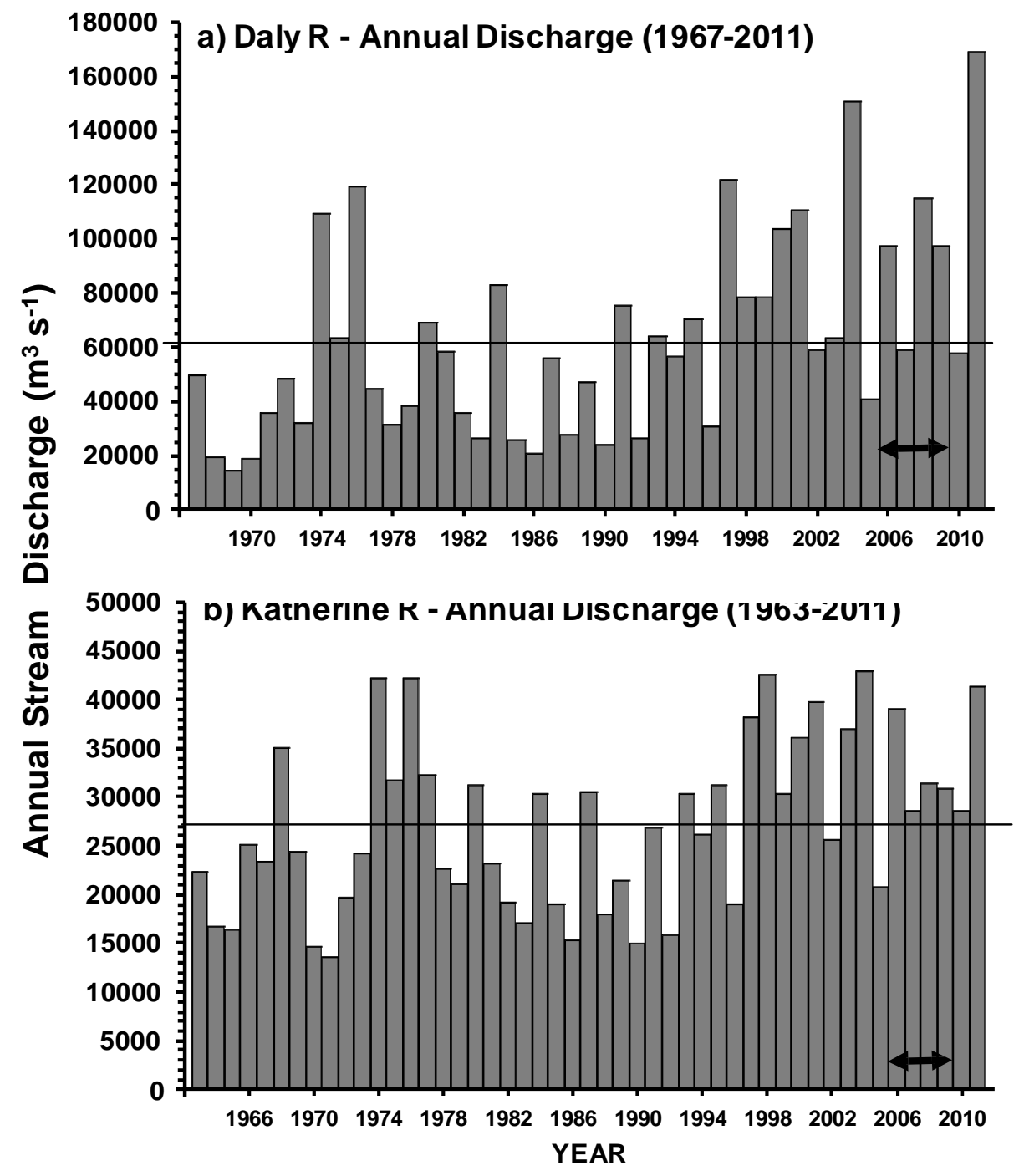

Figure 2. 

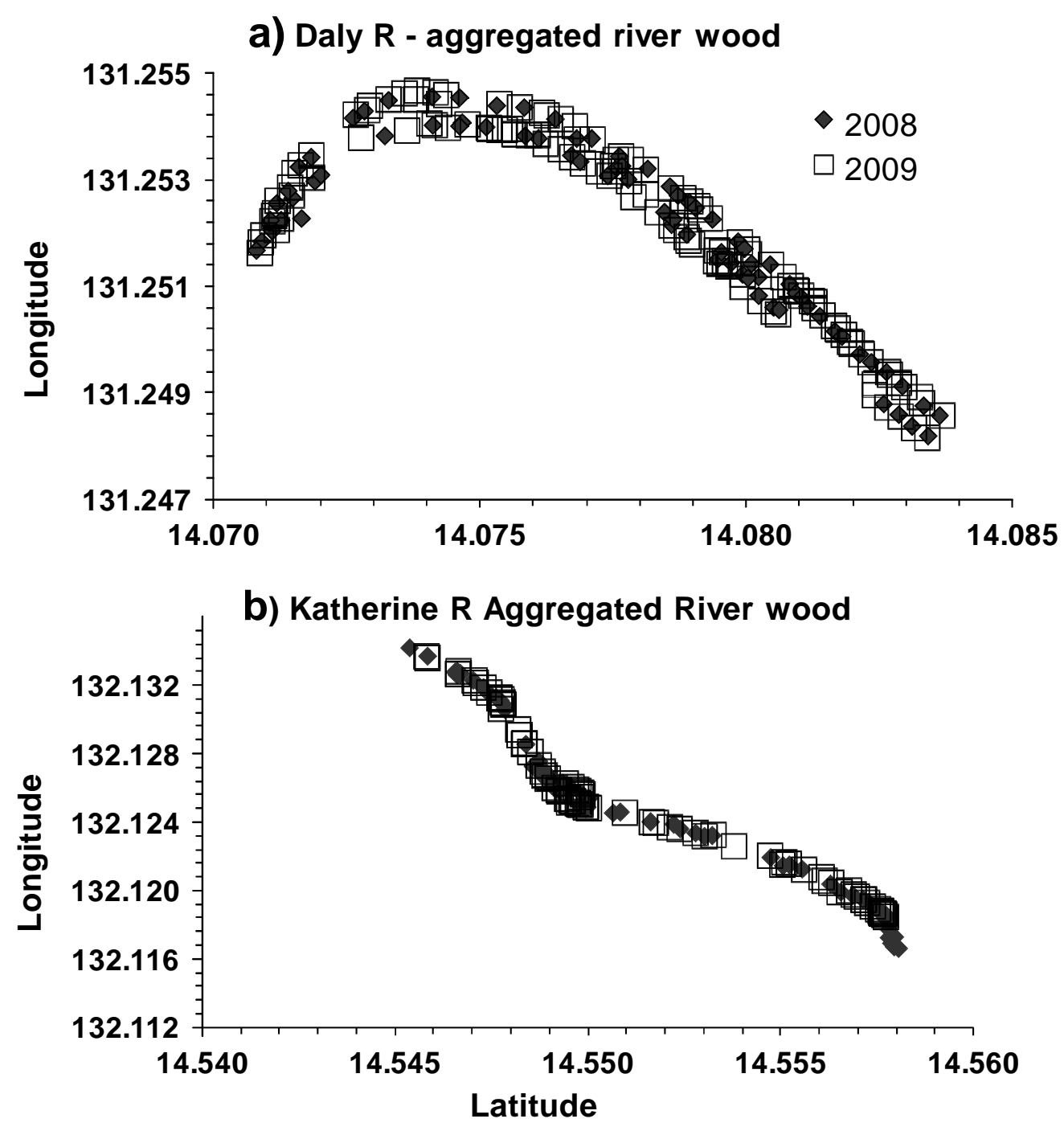

Figure 3. 

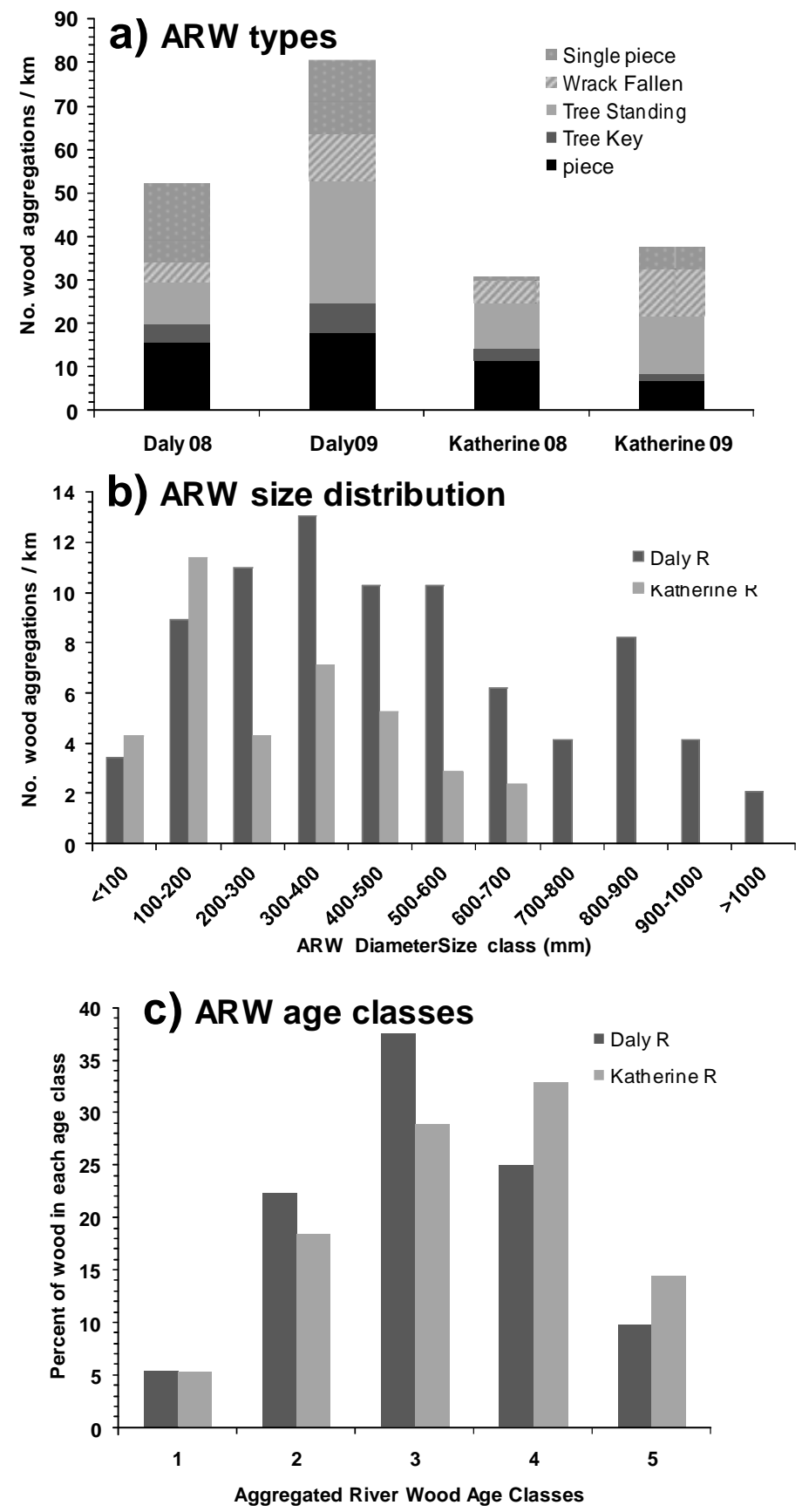

Figure4. 
River wood and fish habitat
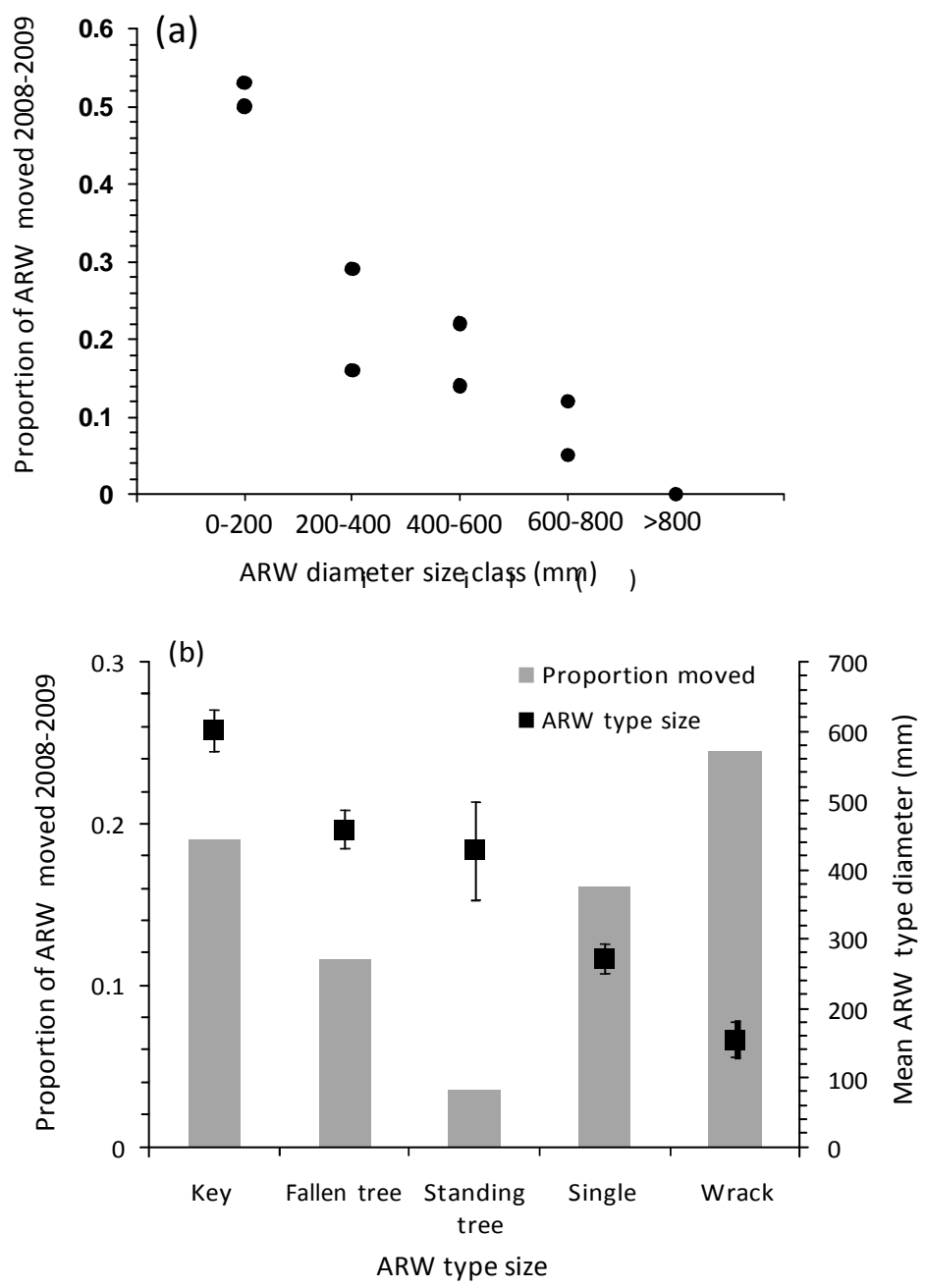

Figure 5. 
River wood and fish habitat

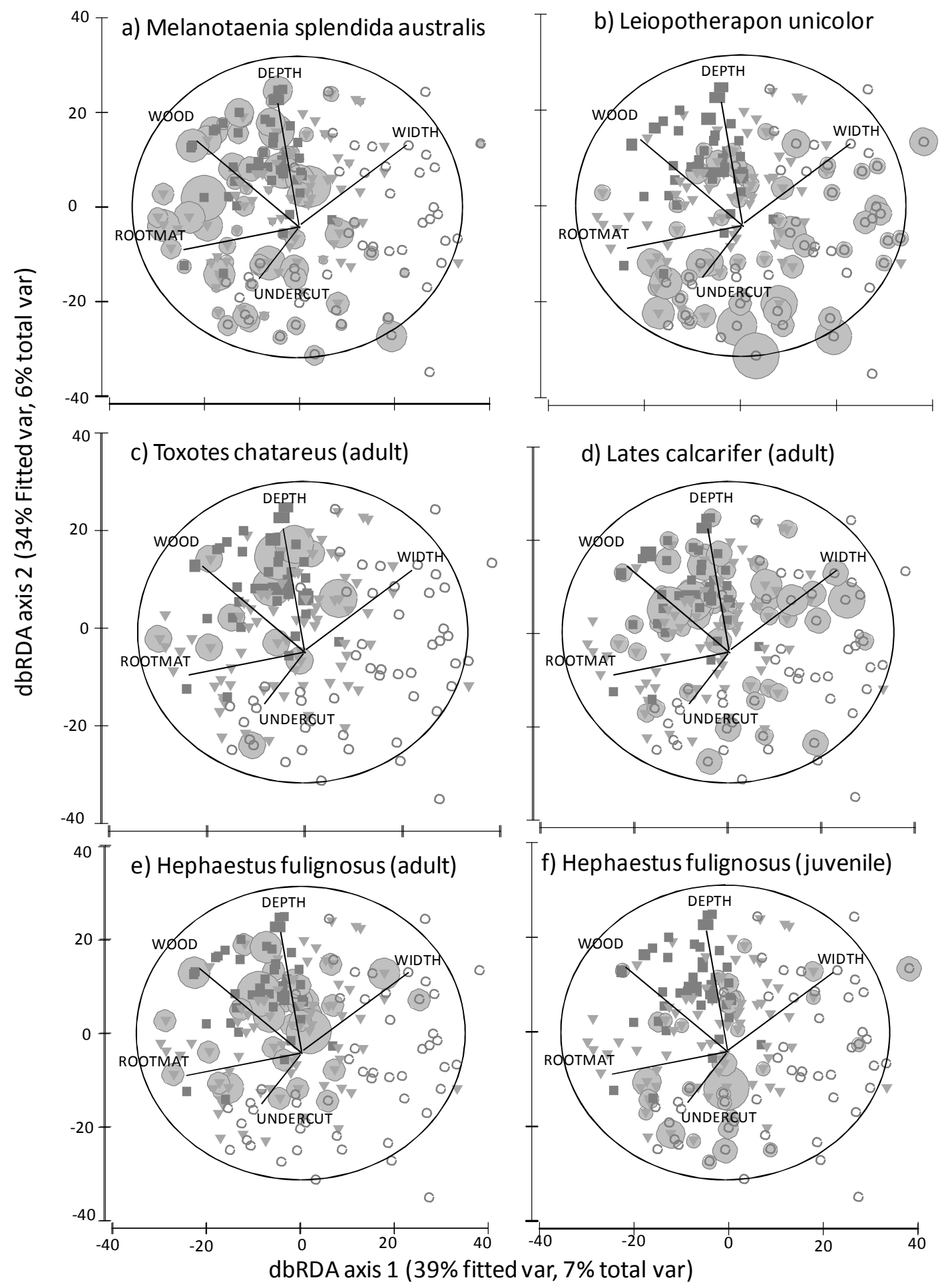

Figure 6. 
River wood and fish habitat

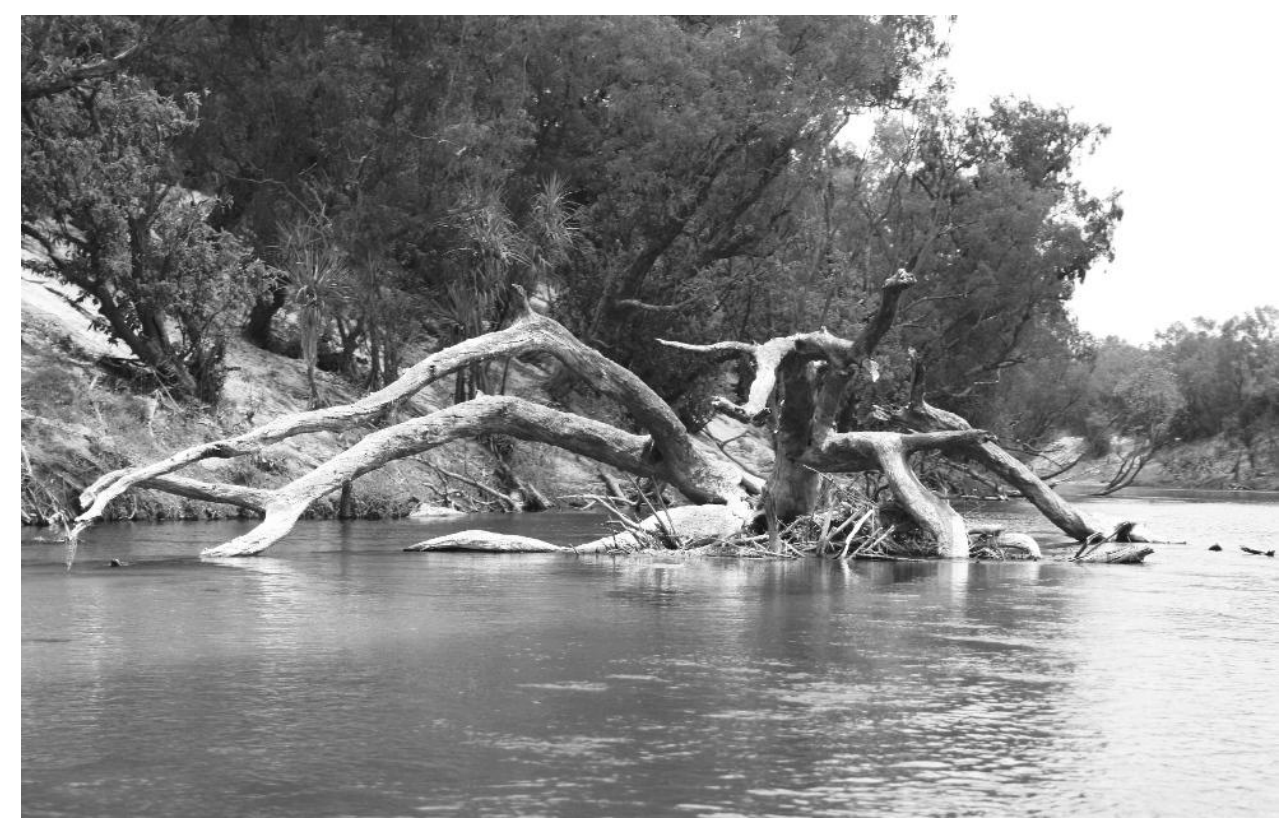

Figure 7: 